\title{
PENGARUH METODE LATIHAN DAN KOORDINASI \\ TERHADAP KETERAMPILAN CHEST PASS \\ DALAM PERMAINAN BOLABASKET
}

\author{
Wahyu Jayadi \\ FIK Universitas Negeri Makassar (email: wahyu_jayadi@yahoo.com)
}

\begin{abstract}
Abstrak: Pengaruh Metode Latihan dan Koordinasi terhadap Keterampilan Chest Pass dalam Permainan Bola Basket. Penelitian ini bertujuan untuk mengetahui pengaruh latihan pliometrik dan latihan beban secara konvensional terhadap keterampilan chest pass dalam permainan bolabasket ditinjau dari koordinasi mata tangan. Penelitian eksperimen ini dirancang dengan faktorial group design dengan 2 x 2 dan dilaksanakan di SMA Negeri 1 Sinjai Selatan Kabupaten Sinjai Propinsi Sulawesi Selatan dengan sampel 60 siswa putra. Data dianalisis dengan menggunakan analisis Varian yang dilanjutkan dengan uji Tukey. Hasil penelitian menunjukkan hal-hal sebagai berikut. (1) Secara keseluruhan keterampillan Chest Pass pada kelompok siswa yang diberi perlakuan dengan metode latihan pliometrik lebih baik dibandingkan dengan kelompok siswa yang diberi perlakuan dengan metode latihan beban secara konvensional. (2) Kelompok siswa yang memiliki koordinasi mata tangan tinggi yang diberi perlakuan metode latihan pliometrik lebih baik dibandingkan dengan kelompok siswa yang memiliki koordinasi mata tangan tinggi yang diberi perlakuan metode latihan konvensional. (3) Kelompok siswa yang memiliki koordinasi mata tangan rendah dan diberi perlakuan metode latihan pliometrik lebih rendah dibandingkan dengan kelompok siswa yang memiliki koordinasi mata tangan rendah dan diberi perlakuan metode latihan konvensional. (4) Terdapat interaksi antara pemberian metode latihan dan koordinasi mata tangan terhadap keterampilan chest pass pada kelompok siswa.
\end{abstract}

Kata Kunci: metode latihan, koordinasi, keterampilan chest pass, permainan bola basket

\begin{abstract}
The Influence Training and Coordination Towards Chest Pass Skill in Basket Ball. The objective of this research is to find out the influence of plyometric training and conventional loading training towards chest pass skill in basket ball game to be observed from eye and hand coordination. This research was conducted on August 5 until November 5, 2007 at Public Senior High School (SMA Negeri) 1 Sinjai, in South Sinjai, South Sulawesi Province with 60 male students as its sample and done in experimental study with $2 \times 2$ factorial group design. The data were analyzed by using "Anava" (Analysis Varians) and Tukey Test. The result of the research shows that (1) students in experimental group of Chest Pass skill with Ploymetric training method have higher results than those with conventional loading training method; (2) the students who have high eye and hand coordination and they are trained using plyometric method have higher results than
\end{abstract}


students with high eye and hand coordination but they are trained through conventional approach; (3) students who have low eye and hand coordination and they are trained using Plyometric training method have lower results than students with low eye and hand coordination but have conventional training; (4) there is correlation between training method and eye-hand hand coordination toward chest pass training.

Keywords: training approach, coordination, chest pass skill, basket ball

\section{PENDAHULUAN}

Permainan bolabasket adalah salah satu cabang olahraga yang termasuk populer dan banyak digemari oleh masyarakat Indonesia. Kenyataan ini merupakan modal dasar dan peluang untuk mencapai prestasi. Namun, prestasi bolabasket yang didambakan belum dapat terwujud. Oleh sebab itu, sangat diharapkan adanya usaha-usaha pembinaan ke arah peningkatan prestasi. Untuk meningkatkan prestasi olahraga bolabasket, diharapkan memperhatikan generasi penerus yang sekarang ini masih dalam tahap pemula. Menurut Arismunandar (1997:7), untuk menciptakan seorang juara dalam dunia olahraga diperlukan waktu delapan sampai sepuluh tahun, di mana atlet harus berlatih dan berkompetisi sejak usia dini secara berkelanjutan, sistematik, konseptual, dan ilmiah.

Permainan bolabasket memiliki karakteristik tersendiri, antara lain kategori permainan yang rnempergunakan bola besar, lapangan yang luas dan mempunyai papan pantul serta ring untuk memasukkan bola. Di samping itu, prinsip dasar permainan bola basket adalah (1) dribbling; (2) chest pass; (3) shooting; (4) pivot; dan (5) lay up. Aspek- aspek yang terlibat dalam prinsip dasar di atas adalah psikis dan fisik. Keadaan inilah yang mengakibatkan permainan bolabasket lebih sulit dibandingkan dengan permainan lainnya, terutama bagi pemain pemula.

Dalam pembinaan permainan bola basket masih saja sering dijumpai latihan yang hanya ditujukan pada teknik permainan saja, misalnya langsung bermain tanpa memperhatikan latihan-latihan yang menunjang. Padahal, unsurunsur tersebut merupakan satu kesatuan yang tidak dapat dipisahkan. Karena apabila salah satunya terabaikan, maka akan berpengaruh terhadap prestasi bolabasket secara keseluruhan. Salah satu teknik permainan bolabasket yaitu teknik chest pass. Chest pass perlu di kembangkan karena salah satu teknik dasar yang sangat memegang peranan dalam upaya mengoper dalam permainan bolabasket. Tentunya dengan tidak mengabaikan teknik yang lain, dan di samping latihan-latihan fisik, taktik dan mental yang juga turut menunjang pengembangan dan prestasi bermain bolabasket.

Secara khusus, Wissel (2000:72) menjelaskan bahwa chest pass adalah operan yang paling umum dalam per- 
mainan bolabasket karena dapat di lakukan dengan cepat dan tepat dari setiap posisi di atas lantai. Kemampuan gerakan chest pass pada dasarnya ditunjang oleh kekuatan otot-otot lengan.

Midgley (1996:152) mengemukakan bahwa bolabasket adalah permainan yang dimainkan oleh dua kelompok tim yang terdiri dari lima orang pemain. Pemain berhak melempar, menangkap dan memukul bola. Sasaran pertandingan adalah melemparkan bola ke dalam basket (keranjang) tim lawan. Hal ini diperjelas oleh Sodikun (1992: 20) yang mengemukakan bahwa permainan bolabasket merupakan permainan yang gerakannya kompleks, yaitu gabungan dari jalan, lari, lompat dan unsur kekuatan, kecepatan, ketepatan, kelentukan, dan lain-lain. Untuk dapat melakukan gerakan-gerakan bolabasket dengan baik, diperlukan kemampuan dasar fisik yang memadai. Dengan kondisi fisik yang baik, akan memudahkan melakukan gerakan-gerakan yang lebih sulit (kompleks).

Selanjutnya, Wissel (2000:72) mengemukakan bahwa chest pass adalah operan yang paling umum dalam permainan bolabasket karena dapat dilakukan dengan cepat dan tepat dari setiap posisi di atas lantai. Sementara itu, Sarumpaet, dkk. (1992: 224) menjelaskan bahwa chest pass adalah teknik melempar atau mengoper bola dalam permainan bolabasket. Pada umumnya, teknik ini dilakukan dengan dua tangan.

Pendapat yang sama dikemukakan oleh Abidin (1999:42), bahwa operan dada (chest pass) adalah salah satu jenis operan dasar dalam permainan bolabasket.
Pate, dkk (1983:17) mendefinisikan latihan sebagai peran serta yang sistematis dalam latihan yang bertujuan untuk meningkatkan kapasitas fungsional fsik dan daya tahan latihan. Harsono (1988:101) memberi batasan sederhana dari latihan, yaitu proses yang sistematis dari berlatih atau bekerja, yang dilakukan secara berulang-ulang, dengan kian hari kian menambah jumlah beban latihan atau pekerjaannya. Lebih lanjut dijelaskan bahwa yang dimaksud dengan sistematis adalah berencana menurut jadwal, menurut pola dan sistem tertentu, metodis dari mudah ke sukar, latihan yang teratur dari sederhana ke yang lebih kompleks. Berulang-ulang maksudnya ialah agar gerakan-gerakan yang semula sukar dilakukan menjadi semakin mudah, otomatis, dan reflektif pelaksanaannya sehingga semakin hemat energi.

Pate, dkk. (1983:318-320) menyarankan prinsip-prinsip latihan harus mempertimbangkan pembebanan berlebih, konsistensi, kekhususan, kemajuan, ciri pribadi, keadaan pelatihan, periodisasi, masa stabil, tekanan, tekanan dalam berlatih. Harsono (1988:102-113) menyarankan prinsip-prinsip yang mendasar yang harus diperhatikan, yaitu: prinsip beban berlebih, prinsip perkembangan menyeluruh, spesialisasi, individualisasi. Sudarno (1992:65:66) berpendapat bahwa latihan harus berdasarkan pada prinsip beban berlebih, individual, kekhususan dan berkebalikan (reversibility). Prinsip pembebanan berlebih atau lebih dikenal dengan overload principle banyak disarankan oleh beberapa ahli sehingga prinsip ini merupakan prinsip 
yang mendasar dari prinsip-prinsip latihan.

\section{Latihan Pliometrik}

Penggunaan bola medicine dalam latihan ini seberat 9-15 pound, yang dilakukan dengan berpasangan. Pelaksanaannya, siswa berdiri atau duduk dengan saling berhadapan satu sama lain. Seorang siswa memegang bola medicine dengan tangan di belakang bola, kemudian melenturkan atau menolakkan bola ke siswa yang menerima. Siswa yang satu mengantisipasi tolakan bola yang berasal dari pasangannya dengan lengan terbuka luas secara horisontal di dada, bola medicine didorong keluar dengan cepat sambil memanjangkan lengan. Siswa yang lain memperhatikan gerakan tolakan bola secara penuh, kemudian mengembalikan dengan dorongan penuh. Gerakan ini diulangi secara berturut-turut sambil menangkap bola medicine.

\section{Latihan Konvensional}

Latihan beban (weight training merupakan salah atau metode latihan yang paling banyak digunakan oleh pelatih untuk membina dan meningkatkan kondisi fisik anak didik. Metode latihan ini sangat sederhana karena dapat menggunakan peralatan yang sederhana, seperti barbell, dumble, baju beban, dan lain sebagainya. Harsono (1988: 185-199) mengemukakan bahwa metode latihan beban adalah latihan yang menggunakan beban untuk memperoleh peningkatan kekuatan dan kecepatan, dan metode latihan apabila dilakukan dengan benar dapat mengem- bangkan kecepatan, daya ledak, kekuatan dan daya tahan. Selanjutnya, Rahantoknam (1988:146-149) mengemukakan bahwa prinsip-prinsip latihan meliputi (1) overload; (2) spesifikasi; dan (3) program perkembangan umum.

\section{Koordinasi Mata Tangan}

Phillips dan Hornack (1979:251) menjelaskan, koordinasi adalah kemampuan melakukan suatu pola gerakan yang membutuhkan keterampilan. Koordiansi juga merupakan bagian integral dari kemampuan motorik. Pada kenyataannya, pengertian koordinasi telah dianggap sebagai padanan dari kata kemampuan motorik dan keterampilan. Giriwijoyo (1992:82) menjelaskan bahwa latihan atau pengembangan keterampilan teknik berarti mengembangkan kemampuan mengkoordinasikan fungsi saraf otot. Hakikat kemampuan mengkoordinasikan fungsi saraf otot adalah ketepatan dan kecepatan. Selanjutnya, penguasaan kecakapan fisik, khususnya,koordinasimerupakan salah satu tugas utama dalam pencapaian keahlian atau menguasai keterampilan.

Grana dan Kalenak (1991:253) menjelaskan bahwa koordinasi adalah kemampuan otot untuk mengontrol gerak dengan tepat agar mampu mencapai suatu tugas fisik khusus. Sage (1984: 177-179)mengemukakan pendapat yang sama dengan pendapat Bompa bahwa koordinasi umum adalah kemampuan seluruh tubuh untuk menyesuaikan dan mengatur gerak secara simultan pada saat melakukan suatu gerakan. 
Tabel 1. Perbedaan Karakteristik dan ciri-ciri Umum latihan pliometrik dan latihan konvensional

\begin{tabular}{|c|c|}
\hline Latihan Pliometrik & Latihan Konvensional \\
\hline $\begin{array}{l}\text { 1. Latihan disajikan secara keseluruh- } \\
\text { an, mulai dari gerakan pemanasan, } \\
\text { inti, dan pendinginan. }\end{array}$ & $\begin{array}{l}\text { 1. Latihan disajikan secara berurutan } \\
\text { mulai dari gerakan pemanasan, inti, } \\
\text { dan pendinginan. }\end{array}$ \\
\hline $\begin{array}{l}\text { 2. Latihan disajikan secara terperinci } \\
\text { beserta langkah-langkah dan cara } \\
\text { melakukan gerakan. }\end{array}$ & $\begin{array}{l}\text { 2. Latihan diberikan bagian demi ba- } \\
\text { gian dengan langkah-langkah dan } \\
\text { cara melakukannya. }\end{array}$ \\
\hline $\begin{array}{l}\text { 3. Guru Penjas menjelaskan secara } \\
\text { terperinci langkah-langkah dan cara } \\
\text { melakukan gerakan, mulai dari pe- } \\
\text { manasan, inti, dan pendinginan di- } \\
\text { sertai dengan tingkat-tingkat kesu- }\end{array}$ & $\begin{array}{l}\text { 3. Guru Penjas menjelaskan cara me- } \\
\text { lakukan gerakan dari mulai gerakan } \\
\text { pemanasan, inti, dan pendinginan } \\
\text { disertai dengan peragaan dan con- } \\
\text { toh. }\end{array}$ \\
\hline $\begin{array}{l}\text { litan dari latihan. } \\
\text { 4. Siswa diberi kebebasan untuk ber- }\end{array}$ & $\begin{array}{l}\text { 4. Siswa belajar dengan latihan yang } \\
\text { ditentukan oleh guru. }\end{array}$ \\
\hline $\begin{array}{l}\text { latih, sebelum mulai latihan, dan di- } \\
\text { beri kebebasan untuk memilih ben- } \\
\text { tuk latihan yang ada dalam setiap }\end{array}$ & $\begin{array}{l}\text { 5. Siswa mengulang gerakan sesuai } \\
\text { dengan yang ditentukan oleh guru } \\
\text { dalam setiap pertemuan. }\end{array}$ \\
\hline $\begin{array}{l}\text { 5. Siswa diberi kebebasan untuk me- } \\
\text { ngulang-ulang gerakan pada setiap } \\
\text { pertemuan. }\end{array}$ & kelompok. \\
\hline $\begin{array}{l}\text { 6. Umpan balik diberikan secara per- } \\
\text { seorangan. }\end{array}$ & \\
\hline
\end{tabular}

Jensen, Schultz, dan Bangerter (1983: 140)menjelaskan bahwa koordinasi neuromuscular adalah setiap gerak yang terjadi dalam urutan dan waktu yang tepat serta geraknya mengandung tenaga, terjadinya gerak karena adanya kontraksi otot dan otot berkontraksi karena adanya perintah yang diterima dari otak melalui sistem saraf. Pyke (1991:140) mengemukakan bahwa koordinasi neuromuscular secara rinci yaitu koordinasi neuromuscular mencakup koordinasi intra-muscular dan inter-muscular.

\section{METODE}

Populasipenelitianadalah siswa putra SMA Negeri 1 Sinjai Selatan Kabupaten Sinjai Provinsi Sulawesi Selatan. Teknik pengambilan sampel dilakukan dengan cara menggunakan randomized group design. Penelitian ini merupakan studi eksperimen dengan rancangan faktorial group design dengan 2 (dua) kategori. Desain eksperimen ini merupakan serangkaian kegiatan dengan sengaja dilakukan terhadap variabel bebas, yaitu latihan pliometrik dan latihan beban konvensional dalam kete- 
rampilan chest pass pada permainan bolabasket.

Penelitian ini bertujuan untuk mengetahui pengaruh latihan fisik pliometrik dan latihan beban secara konvensional terhadap keterampilan chest pass dalam permainan bolabasket ditinjau dari koordinasi mata tangan.

Terdapat dua macam data yang dikumpulkan yaitu data keterampilan chest pass dan data koordinasi mata tangan. Adapun variabel yang dilibatkan dalam penelitian ini terdiri dari: variabel terikat yaitu keterampilan chest pass, variabel bebas, yaitu: (1) latihan pliometrik dan (2) latihan beban konvensional. Variabel atribut adalah koordinasi mata tangan yang dibedakan atas dua macam, yaitu: (1) koordinasi mata tangan tinggi, dan (2) koordinasi mata tangan rendah.
Data koordinasi mata tangan diperoleh dengan penelitian yang dimaksud ingin melihat pengaruh eksperimen terhadap keterampilan chest pass. Untuk itu, instrumen penelitian yang digunakan pada penelitian ini adalah tes keterampilan chest pass.

Data yang diperoleh melalui tes keterampilan chest pass, dianalisis dengan teknik analisis varians dua jalur pada taraf signifikansi $\alpha=0,05$. Namun, sebelum teknik analisis varians digunakan, terlebih dahulu dilakukan pengujian persyaratan analisis parametrik, yaitu uji normalitas dan uji homogenitas. Uji normalitas dilakukan dengan menggunakan uji Lilliefors. Pengujian homogenitas varians menggunakan uji Bartlett. Untuk mengetahui kelompok perlakuan mana yang lebih unggul, digunakan uji hoc multiple comparison, yaitu uji Tukey.

Tabel 2. Rancangan Faktorial $2 \times 2$

\begin{tabular}{lcc}
\hline Metode Latihan & $\begin{array}{c}\text { Latihan } \\
\text { Pliometrik }\left(\mathrm{A}_{1}\right)\end{array}$ & $\begin{array}{c}\text { Latihan Beban Secara } \\
\text { Konvensional }\left(\mathrm{A}_{2}\right)\end{array}$ \\
\hline Koordinasi Mata Tangan Tinggi $\left(\mathrm{B}_{2}\right)$ & $\mathrm{A}_{1} \mathrm{~B}_{1}$ & $\mathrm{~A}_{2} \mathrm{~B}_{1}$ \\
$\mathrm{~A}_{2} \mathrm{~B}_{2}$ \\
Koordinasi Mata Tangan Rendah $\left(\mathrm{B}_{2}\right)$ & $\mathrm{A}_{1} \mathrm{~B}_{2}$ & $\mathrm{~A}_{2}$ \\
Total & $\mathrm{A}_{1}$ & \\
\hline
\end{tabular}

Keterangan:

A1B1 = Kelompok siswa yang mempunyai koordinasi mata tangan tinggi dan diberikan latihan pliometrik

A2B1 = Kelompok siswa yang mempunyai koordinasi mata tangan tinggi dan diberikan latihan beban konvensional

$\mathrm{A} 1 \mathrm{~B} 2=$ Kelompok siswa yang mempunyai koordinasi mata tangan rendah dan diberikan latihan pliometrik

A2B2 = Kelompok siswa yang mempunyai koordinasi mata tangan rendah dan diberikan latihan beban konvensional 
HASIL

Data hasil penelitian secara lengkap dapat dilihat pada Tabel 3.

\section{Pengujian Persyaratan Analisis}

Uji normalitas dilakukan dengan menggunakan uji Liliefors yang dikenakan pada masing-masing kelompok perlakuan dengan taraf signifikan $\alpha=$ 0,05 . Ada delapan kelompok uji normalitas. Hasil perhitungan pada taraf ke- percayaan $\alpha=0,05$ terlihat bahwa nilai Lhitung untuk semua kelompok lebih kecil daripada Ltabel. Dengan demikian, dapat disimpulkan bahwa data keterampilan chest pass dari semua kelompok data I, II, III, IV, V, VI, VII dan VIII berasal dari populasi yang berdistribusi normal. Untuk lebih jelasnya, hasil uji tersebut secara keseluruhan tercantum pada Tabel 4.

\section{Tabel 3. Deskripsi Data}

\begin{tabular}{|c|c|c|c|c|c|c|c|c|}
\hline $\begin{array}{l}\text { Data } \\
\text { Metode } \\
\text { Latihtikan }\end{array}$ & $\begin{array}{c}\mathrm{n} \\
\text { sampel }\end{array}$ & $\begin{array}{c}\text { Skor } \\
\text { Terendah }\end{array}$ & $\begin{array}{c}\text { Skor } \\
\text { Tertinggi }\end{array}$ & $\begin{array}{l}\text { Rata- } \\
\text { rata }\end{array}$ & $\begin{array}{c}\text { Simpangan } \\
\text { Baku }\end{array}$ & Rentang & Modus & Median \\
\hline Pliometrik & 20 & 10 & 25 & 18,55 & 4,31 & 15 & 23 & 19 \\
\hline Konvensional & 20 & 10 & 24 & 16,50 & 3,40 & 14 & 17 & 17 \\
\hline Tinggi & 20 & 10 & 25 & 19,10 & 4,38 & 15 & 23 & 20 \\
\hline Rendah & 20 & 10 & 21 & 15,95 & 2,82 & 11 & 15 & 16 \\
\hline $\begin{array}{l}\text { Pliometrik } \\
\text { Tinggi }\end{array}$ & 10 & 18 & 25 & 22,10 & 2,02 & 7 & 23 & 22,5 \\
\hline $\begin{array}{l}\text { Konvensional } \\
\text { Tinggi }\end{array}$ & 10 & 10 & 24 & 16,10 & 4,04 & 14 & 14 & 16 \\
\hline $\begin{array}{l}\text { Pliometrik } \\
\text { Rendah }\end{array}$ & 10 & 10 & 20 & 15,00 & 2,67 & 10 & 15 & 15 \\
\hline $\begin{array}{l}\text { Konvensional } \\
\text { Rendah }\end{array}$ & 10 & 12 & 21 & 16,90 & 2,77 & 9 & 17 & 17 \\
\hline
\end{tabular}

Tabel 4. Rekapitulasi Hasil Pengujian Normalitas Data

\begin{tabular}{ccccc}
\hline $\begin{array}{c}\text { Kelompok } \\
\text { Sampel }\end{array}$ & $\begin{array}{c}\text { Jumlah } \\
\text { Sampel }\end{array}$ & Lhitung & Ltabel & Kesimpulan \\
\hline I & 20 & 0,088 & 0,190 & Normal \\
II & 20 & 0,091 & 0,190 & Normal \\
& 20 & 0,096 & 0,190 & Normal \\
III & 20 & 0,105 & 0,190 & Normal \\
IV & 10 & 0,128 & 0,258 & Normal \\
V & 10 & 0,154 & 0,258 & Normal \\
VI & 10 & 0,119 & 0,258 & Normal \\
VII & 10 & 0,086 & 0,258 & Normal \\
VIII & & & &
\end{tabular}


Tabel 5. Hasil Uji Homogenitas Varians Kelompok Data

\begin{tabular}{cccc}
\hline Kelompok & $\chi^{2}$ hitung & $\chi^{2}$ tabel & Kesimpulan \\
\hline $\mathrm{A}_{1}$ dan $\mathrm{A}_{2}$ & 1,07 & 3,84 & Homogen \\
$\mathrm{B}_{1}$ dan $\mathrm{B}_{2}$ & 3,56 & 3,84 & Homogen \\
$\mathrm{A}_{1} \mathrm{~B}_{1}, \mathrm{~A}_{2} \mathrm{~B}_{1}, \mathrm{~A}_{1} \mathrm{~B}_{2}, \mathrm{~A}_{2} \mathrm{~B}_{2}$ & 4,47 & 7,82 & Homogen \\
\hline
\end{tabular}

Uji homogenitas menggunakan uji Bartlet dilakukan terhadap (1) dua kelompok perlakuan $\mathrm{A}_{1}$ dan $\mathrm{A}_{2}$; (2) dua kelompok atribut $\mathrm{B}_{1}$ dan $\mathrm{B}_{2}$; dan (3) empat kelompok sel dalam rancangan eksperimen $\mathrm{A}_{1} \mathrm{~B}_{1}, \mathrm{~A}_{1} \mathrm{~B}_{2}, \mathrm{~A}_{2} \mathrm{~B}_{1}$ dan $\mathrm{A}_{2} \mathrm{~B}_{2}$. Pengujian homogenitas varians melalui pendekatan $\chi^{2}$ dengan kriteria pengujian terima $H_{o}$ jika $\chi^{2}$ hitung $<\chi^{2}$ tabel yang berarti varians homogen dan tolak $\mathrm{H}_{\mathrm{o}}$ jika $\chi^{2}$ hitung $\geq \chi^{2}$ tabel yang berarti varians tidak homogen. Di uji pada taraf kepercayaan $\alpha=0,05 ; \mathrm{dk}=\mathrm{k}-1$.

Berdasarkan Tabel 3 tampak bahwa nilai $\chi^{2}$ hitung dari ketiga kelompok data lebih kecil dari $\chi^{2}$ tabel pada taraf kepercayaan $\alpha=0,05$. Hal ini berarti bahwa keseluruhan kelompok data yang diuji memiliki varians yang homogen.

Hasil pengujian normalitas dan homogenitas data tersebut menunjukkan bahwa kelompok-kelompok data dalam penelitian ini berasal dari populasi yang berdistribusi normal dan memiliki varians yang homogen. Dengan demikian, persyaratan normalitas dan homogenitas data terpenuhi sehingga dapat digunakan Analisis Varians (ANAVA) dalam pengujian hipotesis penelitian.

Pengujian hipotesis dalam penelitian ini dilakukan dengan menggunakan analisis varians dua jalur dan akan diperoleh dua pengaruh utama (main effect) antarkolom sebagai variabel perlakuan dan pengaruh utama antarbaris sebagai variabel atribut (simple effect), serta interaksi (interaction effect) antara kolom dan baris atau antara variabel bebas pendekatan metode latihan dan koordinasi mata tangan siswa terhadap variabel terikat yaitu keterampilan chest pass.

\section{Pengujian Hipotesis}

Pengujian hipotesis dalam penelitian ini dilakukan dengan menggunakan analisis varians dua jalur dan akan diperoleh dua pengaruh utama (main effect) antarkolom sebagai variabel perlakuan dan pengaruh utama antarbaris sebagai variabel atribut (simple effect), serta interaksi (interaction effect) antara kolom dan baris atau antara variabel bebas pendekatan metode latihan dan koordinasi mata tangan siswa terhadap variabel terikat yaitu keterampilan chest pass.

Dengan adanya interaksi dan signifikan pengaruh utama antara bentuk metode latihan dan koordinasi mata tangan dalam analisis varians di atas, maka pengujian dilanjutkan dengan menggunakan uji Tukey antara pasangan data guna menentukan rata-rata kelompok yang lebih tinggi antara dua kelompok data yang dipasangkan seperti ditunjukkan pada Tabel 7. 
Tabel 6 ANAVA Dua Jalur Data Keterampilan Chest Pass

\begin{tabular}{|c|c|c|c|c|c|c|c|}
\hline \multirow{2}{*}{$\begin{array}{l}\text { Sumber } \\
\text { Varians }\end{array}$} & \multirow{2}{*}{$\mathrm{dk}$} & \multirow{2}{*}{ JK } & \multirow{2}{*}{ RJK } & \multirow{2}{*}{ Fhitung } & \multicolumn{2}{|c|}{$\mathrm{F}_{\text {tabel }}$} & \multirow{2}{*}{ Simpulan } \\
\hline & & & & & $\alpha=0,05$ & $\alpha=0,01$ & \\
\hline Metode Latihan (A) & 1 & 42.02 & 42.02 & $4.78^{*}$ & 4.11 & 7.40 & Signifikan \\
\hline $\begin{array}{c}\text { Koordinasi Mata } \\
\text { Tangan (B) }\end{array}$ & 1 & 99.23 & 99.23 & $11.28^{* *}$ & 4.11 & 7.40 & Sangat Signifikan \\
\hline Interaksi A X B & 1 & 156.03 & 156.03 & $17.74^{* *}$ & 4.11 & 7.40 & Sangat Signifikan \\
\hline $\begin{array}{l}\text { Kekeliruan } \\
\text { (dalam Sel) }\end{array}$ & 36 & 316.70 & 8.80 & - & & & \\
\hline TOTAL & 39 & 613.98 & & & & & \\
\hline
\end{tabular}

Keterangan:

$\mathrm{dk}=$ derajat kebebasan $\quad *$ ) $\quad=$ Uji F signifikan (signifikan pada $\alpha=0,05$ )

JK = Jumlah Kuadrat $\quad{ }^{*}$ ) $\quad$ Uji F sangat signifikan (signifikan pada $\alpha=0,01$ )

$\alpha=$ Taraf signifikansi $\quad$ RJK $=$ Rata-rata Jumlah Kuadrad, $(\mathrm{RJK}=\mathrm{JK} / \mathrm{db})$

Tabel 7 : Hasil Uji Tukey antara Kelompok Data

\begin{tabular}{|c|c|c|c|c|}
\hline \multirow{2}{*}{ Kelompok } & \multirow{2}{*}{ Qhitung } & \multicolumn{2}{|c|}{$Q_{\text {tabel }}$} & \multirow{2}{*}{ Kesimpulan } \\
\hline & & $\alpha=0,05$ & $\alpha=0,01$ & \\
\hline$A_{1}-A_{2}$ & $3,09^{* *}$ & 2,09 & 2,86 & Sangat Signifikan \\
\hline $\mathrm{B}_{1}-\mathrm{B}_{2}$ & $4,75^{* *}$ & 2,09 & 2,86 & Sangat Signifikan \\
\hline $\mathrm{A}_{1} \mathrm{~B}_{1}-\mathrm{A}_{2} \mathrm{~B}_{1}$ & $6,40^{* *}$ & 2,26 & 3,25 & Sangat Signifikan \\
\hline $\mathrm{A}_{1} \mathrm{~B}_{2}-\mathrm{A}_{2} \mathrm{~B}_{2}$ & $2,03^{\text {ns }}$ & 2,26 & 3,25 & Non Signifikan \\
\hline
\end{tabular}

Keterangan :

**) =sangat signifikan $\quad$ *) $=$ signifikan $\quad$ ns $=$ non signifikan

Hasil-hasil pengujian seperti pada Tabel 6 dan Tabel 7 dapat dijelaskan sebagai berikut.

Perbedaan Keterampilan Chest Pass antara Kelompok Siswa yang Diberi Perlakuan Metode Latihan Pliometrik n Metode Latihan Konvensional

Hasil perhitungan ANAVA seperti tercantum pada Tabel 6 menunjukkan bahwa nilai Fhitung sebesar 4,78 dan nilai $F_{\text {tabel }}(\alpha=0,05 ; 1 \beta 6)$ sebesar 4,11. Dengan demikian, nilai Fhitung lebih besar dibandingkan dengan niai $F_{\text {tabel }}(\alpha=0,05 ; 1 \beta 6)$, sehingga $\mathrm{H}_{0}$ ditolak dan $\mathrm{H}_{1}$ diterima. Artinya, hipotesis yang menyatakan ter- dapatperbedaan keterampilan chest pass antara kelompok siswa yang diberi perlakuan metode latihan pliometrik dengan kelompok siswa yang diberi perlakuan metode latihan konvensional dapat diterima dengan signifikan.

Untuk menemukan bentuk metode latihan yang lebih baik, analisis dilanjutkan dengan uji Tukey seperti tercantum pada Tabel 7. Hasil perhitungan menunjukkan bahwa nilai Qhitung adalah sebesar 3,09 dan $Q$ tabel $(\alpha=0,05 ; 19)$ adalah sebesar 2,09. Dengan demikian, nilai Qhitung lebih besar dibandingkan dengan Qtabel. Hal ini berarti bahwa perbedaan antara keterampilan chest pass kelom- 
pok siswa yang diberi perlakuan metode latihan pliometrik lebih tinggi dengan kelompok siswa yang diberi perlakuan metode latihan beban konvensional diterima secara signifikan.

\section{Perbedaan Keterampilan Chest Pass pada Kategori Tinggi}

Berdasarkan hasil perhitungan uji Tukey antara kelompok siswa yang memiliki koordinasi mata tangan tinggi dan diberi perlakuan metode latihan pliometrik, diperoleh nilai rata-rata sebesar 22,10. Kelompok siswa yang memiliki koordinasi mata tangan tinggi yang diberi perlakuan metode latihan beban konvensional diperoleh nilai rata-rata sebesar 16,10. Rata-rata kuadrat dalam (RJK(D)) pada ANAVA dua jalur adalah sebesar 8,80. Hasil uji Tukey menunjukkan nilai Qhitung sebesar 6,40 dan nilai $\mathrm{Q}_{\text {tabel }}(\alpha=0,05,9)$ sebesar 2,26. Dengan demikian, nilai Qhitung lebih besar dibandingkan dengan nilai Qtabel $(\alpha=0,05 ; 9)$ sehingga $\mathrm{H}_{0}$ ditolak dan $\mathrm{H}_{1}$ diterima.

\section{Perbedaan Keterampilan Chest Pass pada Kategori Rendah}

Hasil perhitungan uji Tukey kelompok siswa yang memiliki koordinasi mata tangan rendah dan diberi perlaku- an metode latihan pliometrik diperoleh nilai rata-rata sebesar 15,00 dan kelompok siswa yang memiliki koordinasi mata tangan rendah yang diberi perlakuan metode latihan beban konvensional diperoleh nilai rata-rata sebesar 16,90. Rata-rata kuadrat dalam (RJK(D)) pada Anava dua jalur adalah sebesar 8,80 . Hasil uji Tukey menunjukkan nilai Qhitung adalah sebesar 2,03 dan nilai $\mathrm{Q}_{\text {tabel }}(\alpha=0,05 ; 9)$ sebesar 2,26. Dengan demikian, nilai Qhitung lebih kecil dibandingkan dengan nilai $Q_{\text {tabel }}(\alpha=0,05 ; 9)$ sehingga $\mathrm{H}_{0}$ ditolak dan $\mathrm{H}_{1}$ diterima.

Interaksi antara Pemberian Perlakuan Metode Latihan dengan Koordinasi Mata Tangan terhadap Keterampilan Chest Pass Siswa

Hasil pengujian interaksi berdasarkan perhitungan Anava di atas, terlihat bahwa nilai $\mathrm{F}$ hitung sebesar 17,74 dan nilai $F$ tabel $(\alpha=0,05)$ sebesar 4,11 . Dengan demikian, nilai $\mathrm{F}$ hitung lebih besar dibandingkan dengan nilai $F$ tabel $(\alpha=0,05)$ sehingga $\mathrm{H}_{0}$ ditolak dan $\mathrm{H}_{1}$ diterima, yang berarti hipotesis yang menyatakan terdapat interaksi antara pemberian metode latihan dengan koordinasi mata tangan dapat diterima dan terbukti secara signifikan.

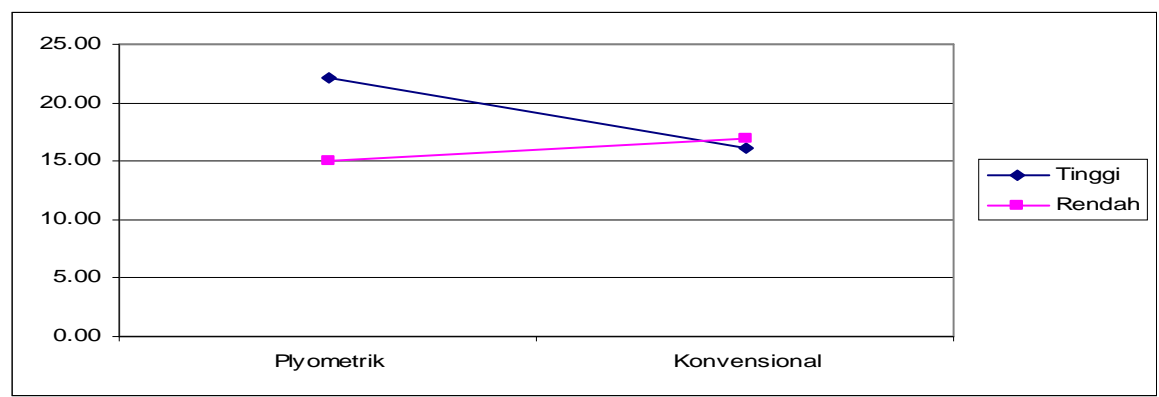

Gambar 1. Interaksi Pemberian Perlakuan Metode Latihan Dengan Koordinasi Mata Tangan Terhadap Rata-rata Keterampilan Chest Pass Siswa 


\section{PEMBAHASAN}

Hasil pengujian hipotesis membuktikan bahwa keterampilan chest pass siswa pada kedua perlakuan memberikan perbedaan yang signifikan. Melalui uji lanjut, terbukti bahwa keterampilan chest pass siswa yang diberi perlakuan metode latihan pliometrik lebih tinggi dibandingkan dengan siswa yang diberi perlakuan metode latihan konvensional.

Perbedaan Keterampilan Chest Pass antara Kelompok Siswa yang Diberi Perlakuan Metode Latihan Pliometrik dengan Kelompok Siswa yang Diberi Perlakuan Metode Latihan Konvensional

Hasil pengujian hipotesis pertama, membuktikan bahwa secara keseluruhan siswa yang belajar dengan metode latihan pliometrik lebih tinggi hasilnya dibandingkan dengan siswa yang belajar dengan metode latihan konvensional. Dalamhalini, dapatdinyatakan bahwa untuk mencapai tujuan, metode latihan pliometrik lebih efektif dibanding dengan metode latihan konvensional dalammeningkatkan keterampilan chest pass.

Efektivitas metode latihan pliometrik dalam latihan karena secara teori metode latihan pliometrik lebih baik dari metode latihan konvensional. Gerakan-gerakan pada keterampilan chest pass merupakan gerakan yang dinamis serta dirangkai menjadi suatu rangkaian gerak lebih cocok dengan kemampuan dasar/motorik yang dimiliki siswa. Pada prinsipnya, koordinasi mata tangan berisikan kekuatan, kecepatan, kelenturan, keseimbangan, kelincahan ser- ta koordinasi sehingga dapat berkontribusi dengan rangkaian gerak yang ada pada keterampilan chest pass. Kontribusi ini sangat besar pengaruhnya sebagai faktor pendukung keberhasilan siswa sewaktu melakukan rangkaian gerak chest pass karena koordinasi mata tangan yang dimiliki sangat memudahkan siswa dalam melakukan tingkat kebenaran gerakan yang sulit dan dinamis.

Metode latihan pliometrik adalah metode latihan yang mengarah pada pencapaian tujuan pembelajaran bolabasket secara efisien, yaitu menguasai keterampilan melalui pengembangan gerakan dengan cepat dan dinamis sesuai dengan tujuan pembelajaran. Di samping itu, pada pembelajaran bolabasket siswa diarahkan pada pembelajaran yang bertumpu pada pengembangan dan pengayaan gerak sehingga titik berat pembelajaran adalah penguasaan keterampilan dan ketangkasan gerak.

\section{Interaksi Antara Pendekatan Metode Latihan Dengan Koordinasi Mata Tangan}

Hasil pengujian hipotesis yang dilakukan membuktikan bahwa ada interaksi antara metode latihan dengan koordinasi mata tangan siswa dan pengaruhnya terhadap keterampilan chest pass. Kelompok siswa yang mempunyai koordinasi mata tangan tinggi dan diberi metode latihan pliometrik mencapai keterampilan chest pass lebih tinggi dibandingkan dengan kelompok siswa yang memiliki koordinasi mata tangan tinggi yang diberi metode latihan konvensional. Hal ini menunjukkan bahwa 
pengaruh pendekatan metode latihan berhubungan dengan karakteristik siswa yang mengikuti pembelajaran bolabasket.

Pada kelompok siswa yang memiliki koordinasi mata tangan rendah yang belajar dengan metode latihan pliometrik mencapai keterampilan chest pass yang lebih rendah dibandingkan dengan kelompok siswa yang diberi metode latihan konvensional. Hal ini juga menunjukkan bahwa pengaruh metode latihan pliometrik juga berhubungan dengan karakteristik siswa yang mengikuti pembelajaran.

Daya pembeda (diskrepansi) yang cukup menyolok antara pengaruh metode latihan pliometrik yang diberikan pada siswa yang memiliki kecenderungan koordinasi mata tangan tinggi dan yang diberikan pada kelompok siswa yang memiliki koordinasi mata tangan rendah. Demikian juga halnya dengan adanya perbedaan pengaruh metode latihan konvensional yang diberikan pada kelompok siswa yang memiliki koordinasi mata tangan tinggi maupun yang diberikan pada kelompok siswa yang memiliki koordinasi mata tangan rendah.

Efektivitas pendekatan metode latihan pada kelompok siswa yang memiliki koordinasi mata tangan tinggi, terkait dengan sifat subjek siswa dan model interaksi pembelajaran yang tercipta oleh metode latihan pliometrik itu sendiri. Siswa yang memiliki koordinasi mata tangan tinggi mempunyai sifat lebih mandiri (independen), dalam melakukan kegiatan pembelajaran seperti mengikuti pembelajaran, mendengarkan informasi, membaca rangkaian gerak serta melakukan latihan ataupun eksperimen, dan sebagainya. Sebaliknya, pada siswa yang memiliki koordinasi mata tangan rendah, penggunaan metode latihan konvensional dalam pembelajaran bolabasket mencapai hasil yang lebih tinggi jika dibandingkan dengan penggunaan metode latihan pliometrik.

\section{PENUTUP}

\section{Kesimpulan}

Pertama, secara keseluruhan keterampilan chest pass pada kelompok siswa yang diberi perlakuan dengan metode latihan pliometrik lebih baik dibandingkan dengan kelompok siswa yang diberi perlakuan dengan metode latihan beban konvensional.

Kedua, kelompok siswa yang memiliki koordinasi mata tangan tinggi yang diberi perlakuan metode latihan pliometrik lebih tinggi (lebih baik) dibandingkan dengan kelompok siswa yang memiliki koordinasi mata tangan tinggi yang diberi perlakuan metode latihan beban konvensional.

Ketiga, kelompok siswa yang memiliki koordinasi mata tangan rendah dan diberi perlakuan metode latihan pliometrik lebih rendah dibandingkan dengan kelompok siswa yang memiliki koordinasi mata tangan rendah dan diberi perlakuan metode latihan beban konvensional.

Keempat, terdapat interaksi antara pemberian metode latihan dengan koordinasi mata tangan terhadap keterampilan chest pass pada kelompok siswa. 


\section{Saran}

Berdasarkan kesimpulan hasil penelitian dan implikasi sebagaimana diuraikan di atas, diketengahkan saransaran sebagai berikut:

Pertama, disarankan kepada para guru pendidikan jasmani, pelatih, dan pembina olahraga untuk mengembangkan metode pembelajaran yang mengacu pada metode latihan pada keterampilan chest pass, selain metode latihan juga harus memperhatikan koordinasi mata tangan. Dengan koodinasi mata tangan tinggi tampaknya metode latihan pliometrik lebih efektif dari pada metode latihan beban konvensional, akan tetapi untuk koordinasi mata tangan rendah tidak terdapat perbedaan yang signifkan. Banyak kombinasi koordinasi mata tangan yang dapat dimanipulasi dalam latihan, mulai dari intensitas maksimal, submaksimal, sedang, intermediate dan rendah. Tiaptiap individu adalah berbeda, sehingga dalam pencapaian hasil yang optimal dari keterampilan chest pass.

Kedua, pemberian metode latihan harus disesuaikan dengan kondisi siswa sehingga perlu penelitian lanjutan dengan memperhatikan metode latihan yang lain.

\section{DAFTAR PUSTAKA}

Abidin, Akros. 1999. Buku Penuntun Bolabasket Kembar (Jakarta: Raja Grafindo Persada.

Arismunandar, Wismoyo. 1997. "Pemantapan Potensi Keolahragaan dan Implikasinya terhadap Manajemen Keolahragaan Daerah". Makalah disampaikan dalam Konferensi Na- sional Pendidikan Jasmani dan Olahraga. Bandung 28 Oktober.

Giriwijoyo, Y.S. Santoso. 1992. Ilmu Faal Olahraga. Bandung: FPOK IKIP.

Grana, William A. and Kalenak, Alexander. 1991. Clinical Sport Medicine. New York: W. B. Sounders Company.

Harsono. 1988. Coaching dan Aspek-aspek Psikologis dalam Coaching. Jakarta: CV. Tambak Kusuma.

Harsono. 1991. Latihan Kondisi Fisik. Jakarta: KONI Pusat.

Midgley, Rud. 1996. Ensiklopedi Olahraga. Semarang: Dahara Prize.

Pate, Russel. dkk. 1983. Dasar-dasar Ilmiah Kepelatihan, Semarang: IKIP Semarang.

Phillips, D. Allen and Hornack, E. 1979. Measurment And Evaluation in Physical Adication, New York: Jhon Wiley \& Sons.

Pyke, Frank S. 1991. Better Coaching Advanced Coachs Mannual. Canberra: Australian Coaching Councyl Incorporated.

Rahantoknam, Edward B. 1988. Belajar Motorik: Teori dan Aplikasinya dalam Pendidikan Jasmani dan Olahraga. Jakarta P2LPTK. Dikti Depdikbud. 
Sage, George H. 1984. Motor Learning and Control a Behavioral Emphasis. Champaign: Human Kinetics Publisher, Inc.

Sarumpaet, A. dkk.1992.Permainan Bolabasket. Jakarta: Depdikbud, Direktorat Jenderal Pendidikan Tinggi, Proyek Pembinaan Tenaga Kependidikan.
Sodikun, Imam. 1992. Olahraga Pilihan Bolabasket. Jakarta: Depdikbud, Direktorat Jenderal Pendidikan Tinggi, Proyek Pembinaan Tenaga Kependidikan.

Sudarno. 1992. Pendidikan Kesegaran Jasmani Jakarta: Departemen P \& K.

Wissel, Hal. 2000. Bolabasket Dilengkapi dengan Program Pemahiran Teknik dan Taktik. Jakarta: PT. Rajagrafindo Persada. 